\title{
Differences of Opinion: The Debate on Thai Theravāda Bhikkhunīs
}

\author{
Pichayapa Suenghataiphorn \\ Mahidol University
}

\begin{abstract}
This paper attempted to summarize the findings regarding the question about the acceptance of Theravāda bhikkhunīs in Thai society across different sections of the Thai population. The statistics approach to this research article and questionnaire sample is cross-sectional data from April 20 to May 12, 2017. Interviews and group discussions have also been utilized as a method to facilitate an open-conversation atmosphere to get our subjects speaking. Nevertheless, since the questionnaire method is anonymous, our subjects feel more at ease to express their opinions regarding the Theravāda bhikkhuni ordination debate in Thailand. Thus, it is hoped that this paper provide a better comprehension of how the Thai people perceive the role of Theravāda bhikkhunī in Thai Buddhist culture and the possibilities for their recognition in the future. Moreover, it is hoped that this research will reveal how the Thai Theravāda bhikkhunīs perceive themselves in their role inside the fourfold assembly consisting of bhikkhus, bhikkhunīs, lay men, and lay women in propagating the Gotama Buddha's teachings.
\end{abstract}

Keywords

: BHIKKHUNĪ, SĀMANERĪ, MAE-CHI, CHI-PHRAM, SINGLE ORDINATION, DUAL ORDINATION

Article Received: 10 August 2020, Revised: 25 October 2020, Accepted: 18 November 2020

\section{Introduction}

In Thailand, the controversy of instating the Theravāda Bhikkhunī Order in Thailand is a huge issue among Thai Sangha and society. The ordination of Chatsumarn Kabilsingh as a sāmaṇerī in $2001 \mathrm{CE}$ was a hot-hit issue in the newspapers. It became a heavily debated issue that did not stop until a member of Thaksin's cabinet, Mr. Wissanu Kreu-ngam (วิษณุ เครืองาม) stepped out to defend Theravāda bhikkhunī ordination as neither right nor wrong as defined by Thai constitution laws. Currently in Thailand, there are around 300 Theravāda bhikkhunīs $(0.00042 \%$ of the Thai population). Female candidates for Theravāda bhikkhunī ordination still have to seek upasampadā ordination outside Thailand due to the non-acceptance of Theravāda bhikkhunī status under the Thai law and by the Thai Sangha. Thus, in this research article, I will examine the controversy concerning the establishment of the Theravāda Bhikkhunī Order in Thailand. I will analyze the reasons given from each side of the dispute either for or against within the internal structure of the Thai debate. I will also study the differences between the attitudes of Thai males and females on the subject.

\section{Methodology of the Research}

The approach to this research article I have conducted is both qualitative and quantitative. My data collection included both primary sources such as interviews, questionnaires, and participant observation. For secondary sources, information from popular and academic books, and journal articles has been used.

Questionnaire (primary source): Questionnaire sample has been collected from 80 bachelor degree students (including monks and novices) at the College of Religious Studies, Mahidol University $(\mathrm{m}=38, \mathrm{f}=42)$ concerning their opinions on the instating of the Bhikkhuni Order in Thailand. Another set of questionnaires has also been collected from 39 blue-collar factory workers $(\mathrm{m}=13, \mathrm{f}=26)$ from Siam
Pokaphan Company to get their opinions and also test their knowledge about Theravāda Bhikkhunī Order in Thailand. After the procedure was completed, the Microsoft Excel program has been used to analyze the data.

Interview (primary source): Interviews have been conducted with two bhikkhunīs, one sāmaṇerī, and one female practising lawyer at Songdhammakalyani Monastery. Interviews have also been conducted with two female monastics at Rom Rune Green Park village. Moreover, qualitative information from the lay people $(\mathrm{m}=2, \mathrm{f}=6)$ who give alms to these female monastics from Wat Songdhammakalyani and at Rom Rune Green Park village has been gathered through interviews. I interviewed three mae-chis from Wat Paknam Phasi Charoen and two maechis from Wat Mahadhat. Moreover, scholars from Thammasart University (three male professors) and from Mahachulalongkornrajavidyalaya University (one mae-chi scholar, and one monk scholar) were also interviewed. Out of these three male professors from Thammasat University, I have targeted one with legal questions to determine the influence of the Thai constitution and international laws have on the decision of females to ordain as a bhikkhunī in Thailand. These legal questions were aimed at determining the possibilities for the Thai Sangha to grant the legal recognition of Thai Theravāda bhikkhunīs. Futhermore, I have conducted interviews with one monk from Wat Mahadhat and one monk from Wat Paknam. An interview with one monk who used to belong to the Sangha Supreme Council of Thailand between the years 1992 to $2001 \mathrm{CE}$ from Wat Ratcha Orasaram was carried out. Additionally, I have interviewed one monk from Wat Suthat Thepwararam. Overall, my interview sample size consists of four bhikkhunīs, one sāmaṇerī, six-mae-chis, five monks, three male professors, one female practising lawyer, and eight villagers $[\mathrm{m}=2, \mathrm{f}=6]$. A voice recorder has been used to collect data, but these people may choose to remain anonymous. Written interviews through e-mail would be used at the last resort if the interview subject preferred to use this method in answering questions. 
Participant Observation (primary source): I have spent ten days at Songdhammakalyani Monastery as a volunteer to observe the bhikkhunīs' and sāmaṇerīs' lifestyle, deportment, ritual practice, and their strictness in following the Vinaya by travelling from home back and forth. As a volunteer, I have participated in the monastery's ritual activities. I also had the chance to help with the temple chores, such as offering assistance to the bhikkhunīs and sāmanereīs on their alms-round. In this process, I have observed the interactions between the laity and bhikkhunīs and sāmaṇerīs.

\section{Keywords:}

Bhikkhunī - Pali term for female monk in Buddhism, who follows 311 precepts in the Theravāda tradition and 348 precepts in Dharmaguptaka tradition, and has received higher (upasamapdā) ordination.

Sāmaṇerī - Pali term for female novice in Buddhism, who follows the 10 precepts and has received lower ordination.

Mae-chi - A term for women who undertake the 8 precepts, practice Buddhism and meditation, wear white robes, shave their heads and brows, and lived in either nunneries (samnak-chis) or in a segregated place in temples away from monks.

Chi-phram - A term for women who take the 8 precepts and wear white clothes similarly to mae-chis, but are only temporarily ordained and do not shave their heads and brows. They lived in a separate quarter from the monks, but usually help the mae-chis with the temple chores, such as cooking.

Single Ordination - The Buddha's original authorization for bhikkhus to ordain bhikkhunīs when the community of bhikkhunīs had not yet come into existence. There are 24 sexual questions that the female candidate must answer fully about herself in order to pass and be qualified for the ordination.

Dual Ordination - A type of ordination procedure authorized by the Buddha in which the female candidate seeks higher ordination from both bhikkhunī and bhikkhu communities. The Buddha invented this method when there is one bhikkhuni who got very embarrassed when interrogated by assembly of bhikkhu with 24 sexual questions. In peripheral areas where Sangha members are hard to find, the candidate seeking higher ordination must be ordained by a minimum of 5 bhikkhunīs and 5 bhikkhus. However, in locations that are near a monastic community, and therefore more convenient, the usual norm of performing dual ordination consists of 10 bhikkhunīs and 10 bhikkhus.

\subsection{Bhikkhunīs, sāmaṇerī and monks}

From my interviews with bhikkhunīs and monks, the majority of their opinions contradict each other sharply. The "status" of Theravāda bhikkhunīs and sāmanerēs is not acceptable in Thailand yet, unlike mae-chis and chi-phrams. In Thailand, Theravāda bhikkhunīs are only regarded as female monks by some. Additionally, Thai monks tend to argue that Theravāda Buddhism follows the Vinaya strictly, in which the ordination of Theravāda bhikkhunīs is now invalid. Furthermore, these monks usually ordain as part of the Thai tradition to bring merit to their parents and also for educational opportunities to study from primary level education and above (S.J. Tambiah 1980: 98-99). In Thai culture, it is respectful that young men followed the traditional norms of ordaining as a monk to repay the debt they incurred from their parents for their upbringing. Moreover, the upasampadā ordination ceremony in the Thai culture is perceived as a rite of passage marking the transition from boy to adulthood and as a form of paying respect to their ancestors (S.J. Tambiah 1980: 97, 101).

Nevertheless, Theravāda bhikkhunīs argue that the single ordination method was never abolished from the Vinaya and, thus, the revival of the bhikkhunī ordination lineage could be accomplished (Anālayo 2013: 327). Found in the Pali text and according to Bhikkhunī Dhammavijjā (ธัมมวิชา), the Buddha said that "small rules could be amended" before his parinibbāna. I will give an example of a small rule that is no longer used today. For example, it is now impossible for monastics to avoid touching money, as it is no longer applicable in Thai modern society. Likewise, some monks argue that single ordination procedure could still be valid as "small rules could be amended." However, most of the Thai Theravāda monks disagreed on this issue, and come up with the argument concerning verification of "what is minor" and "what is major" (Duan Kamdee 2001: 259). The primary motivation of the majority of Thai females who chose to ordain as a Theravāda bhikkhunī is to escape from sufferings in samsara. According to Sāmaṇerī Dhammaparipuṇnā (ธัมมปริปุมณา), who has a PhD, the question should be posed to the Thai monks that if females can attain enlightenment in their lay state, then why should males receive their upasampadā ordination as a bhikkhu, since they can attain enlightenment in their lay state as well? According to the majority of the monks, dual ordination is the only correct method in the present day to ordain bhikkhunīs.

According to Phra Sunthorn Ñāṇsundaro (สุนทร ญาฌสุนุทโร), one of my informants, who is also a highly ranked and respected elder monk, believes that even if the Thai King Rama III wanted his daughter to be ordained as a sāmanererī, this could not be accomplished because it went against the Vinaya. Even if the King Rama III was the highest political authority figure in Thailand at his time, his power was limited when compared to the Buddha's Vinaya. Found in the Pali text, and according to Phra Mahā Sawai Dhīrasobhaṇo (ไสว ถีรโสภโณ), a Vipassana meditation teacher at Wat Mahadhat, the Buddha foresaw that if the ordination of bhikkhunīs was permitted, it would result in the reduction of the time-span of the Buddhist religion. Nevertheless, Phra Mahā Sawai Dhîrasobhaṇo is the only monk in my sample who is pro-bhikkhunī ordination, to which he argues that Thai females wanted more acceptance by society by ordaining as a sāmaṇerī or as a bhikkhunī rather than becoming a mae-chi. Phra Mahā Somboon (สมมูรณ์ วุฑุฒิกโร) is the only monk who is neutral, whereas the rest of the monks from my interview sample are opposed to Theravāda bhikkhunī ordination in Thailand.

Bhikkhunī Dhammavaṇṇā (ธัมมวัณณา), and Sāmaṇerī Dhammaparipunnāa, seem to state that female laity feel much more comfortable and at ease with bhikkhunīs and sāmanereīs, since they are able to get closer to each other due 
to their common gender. The female ordained monastics (Bhikkhun̄̄ Dhammavaṇnāa, Bhikkhun̄̄ Dhammakaruṇā ธัมมกรุณา, and Sāmaṇerī Dhammaparipuṇn̄ā) argue that it was the Buddha's intention in the first place for there to be a fourfold assembly consisting of bhikkhus, bhikkhunīs, sāmaṇeras, and sāmaṇerīs to help propagate his teachings. Moreover, the majority of the ordained female monastics in my interview sample believe that both men and women have equal potential to achieve enlightenment as a sotāpanna, sakadāgāmi, anāgāmi, and as an arahant. According to Bhikkhunī Dhammavijjā, it might be possible for the King Rama $X$ to pass a report approving Theravāda bhikkhunī ordination in Thailand during his reign, because the new Thai Sangha Act 2018 CE conferred the sole governing power of the Thai Sangha on the Thai King. Nevertheless, Phra Mahā Wirat's opinion contradicts sharply with that of Bhikkhunī Dhammavijjā; he says that it is very unlikely for there to be a review of the $11^{\text {th }}$ Supreme Patriarch's command in the year $1928 \mathrm{CE}$ (พ.ศ. 2471) forbidding the ordination of Thai females as sāmaṇerīs, sikkhamānās, and bhikkhunīs. Moreover, Phra Sunthorn Ñāṇsundaro suggests a solution for these Thai female ordained monastics to retain their status as only a mae-chi or to go receive upasampadā ordination outside the country. This is due to the fact that the Thai Sangha perceives that the lineage of Theravāda bhikkhunīs has already gone extinct (Peter Koret 2012: 131). Dual ordination is therefore the only correct method to conduct upasampadā ordination in the Thai Sangha's view, and that the Thai bhikkhus still must obey the command of the $11^{\text {th }}$ Thai Supreme Patriarch forbidding the ordination of Thai females by Thai monks (Dhammanandā 2010: 151) .

\subsection{Bhikkhunīs, sāmanerī and mae-chis}

From my interview sample, bhikkhunīs come from a more elite class, have higher education than mae-chis, are more independent, and they do not want to be servants to monks. In contrast, mae-chis tend to come from a lower class, have lower education, and help monks with their daily chores. There are many reasons that Thai females chose to become a mae-chi. The main primary reason given by half of the maechis in my sample is for educational opportunities. However, I argue that becoming a mae-chi can also be for the means of subsistence (livelihood) as well. Moreover, these mae-chis seem not to mind doing chores for the monks and are rather happy with their routine tasks. (One exception is mae-chi Nahathai, who said that she does not have that much time because she has to teach). Nevertheless, there is a prejudice in Thailand, commonly held by the Thai laity, that women who ordain as a mae-chi are perceived as "heartbroken" females seeking an asylum in Buddhist sanctuary (Monica Lindberg Falk 2000: 64). According to both Maechi Kritsana and Mae-chi Nahathai, the bhikkhunīs' robes are considered merely a type of ordained monastic uniforms. Thus, wearing the bhikkhunī's robes is pointless if the female ordained monastic cannot get rid of her kilesa. According to Mae-chi Boonrueng, if wearing the bhikkhunī's robes is for gaining honor, prestige and respect from the Thai laity for them to "krap" (กราบ) and "wai" (ไหว้) the bhikkhunīs, then this should not be the real motive for their ordination. Therefore, the real motive for upasampadā ordination should be to practice dhamma. Thus, Mae-chi Nahathai concludes that this is why she believes the status of bhikkhunīs and mae-chis are equal.

According to Sāmaṇerī Dhammaparipuṇnā and Bhikkhun̄̄ Dhammakarunāa, Thai society is much more accustomed to seeing and making merit with mae-chis rather than with bhikkhun̄is and sāmaṇerīs. Nevertheless, Bhikkhun̄̄ Dhammavijjā argues that these three groups of Thai females in Buddhism are all oppressed in Thai society. Thus, Bhikkhun̄̄ Dhammadatā (ธัมมทัตตา) argues that their status is the same because of the discrimination. This sharply contradicts with Bhikkhun̄ Dhammavaṇnā's opinion who argues very strongly that mae-chis have no status in Thai society because they are not considered "ordained." Moreover, the majority of these female ordained monastics (bhikkhunīs and one sāmaṇerī) from my interview sample seem to believe that mae-chis are only considered as upāsikās, and not as a pabbajita (บรรพชิต).

\subsection{Mae-chis and monks}

Most of the men in the rural areas tend to ordain for educational opportunities to study from primary level and above (S.J. Tambiah 1980: 97-99). This is the same case for females who chose to ordain as a mae-chi which is also for educational opportunities (Janet Gyatso 2010: 9). However, some of them ordained as a monk or chose to become a mae-chi for means of subsistence as well (Swearer 1995: 47, and Muecke 2004: 224). Most of the Thai monks and maechis do not support Theravāda bhikkhunī ordination in Thailand. The majority of them think that it is already sufficient enough for females to become a mae-chi. However, there is one mae-chi, Juntai, who would like to ordain as a bhikkhunī if it will help raise her status and pāramī to a more advanced level. Phra Mahā Tongdi (พระมหาทองดี), who used to belong to the Thai Sangha Supreme Council, has the strongest reaction against Theravāda bhikkhunī ordination in Thailand. He argues that if we wanted to re-establish the Theravāda bhikkhunī ordination lineage again, then the Tipitaka would have to be torn out. He elaborates further that if Theravāda bhikkhun̄ ordination were permitted in Thailand, disastrous consequences would occur, resulting in the end of Thai Buddhism. The majority of the mae-chis I interviewed are ambivalent concerning the issue of Theravāda bhikkhun̄ ordination in Thailand when compared to the Thai monks. Most of the monks seem to show their strong resistance outright (Tongdi, Wirat วิรัตน์, Sunthorn). Nevertheless, there are two mae-chis (Nahathai, Kristina) who are clearly opposed to Theravāda bhikkhunī ordination in Thailand. Mae-chi Boonrueng, and mae-chi Mupin are satisfied with their status and see no need for Thai females to ordain as a bhikkhunī.

\subsection{Professor, practising lawyer and Mahidol BA students from College of Religious Studies}

For my research, I interviewed one practising lawyer, Dr. Kanjana Suthikul and one professor "Dr. Montree," asking legal questions. Dr. Kanjana is strongly pro-bhikkhunī ordination in Thailand, whereas Dr. Montree is against 
Theravāda bhikkhun̄̄ ordination. Dr. Kanjana Suthikul works as a lawyer for Bhikkhunī Dhammanandā, although she never studied in any fields of law. Bhikkhunī Dhammanandā is the first Theravāda bhikkhunī in Thailand who ordained from the Siyam nikāya tradition in Sri Lanka. According to Dr. Kanjana, she believes that the majority of Thai monks are trying to monopolize power, by not accepting the validity of Theravāda bhikkhunī ordinations in Thailand, and also by not permitting the other organizations to touch them. I find her answer similar to only two of the female ordained monastics (sāmaṇerī and bhikkhunī) who agreed that the Thai Sangha is trying to monopolize power. The rest of my interviewees did not dare to criticize the Thai Sangha in this direct manner. Nevertheless, Phra Mahā Tongdi who used to belong to the Thai Sangha Supreme Council replied very directly that the Thai Sangha Supreme Council is trying to monopolize power by not accepting the legitimacy of Thai Theravāda bhikkhunīs although he did not explain his reasoning to me why.

From looking at the questionnaires completed by the CRS students in April 2017, when the students are asked whether the Thai monks are trying to monopolize power or not, $43.75 \%$ (35) of them answered "I'm neutral," 26.25\% (21) answered "I agree," and only 12.5\% (10) answered "I agree very much." I think that since the questionnaire is anonymous, the students are much more out-spoken about their feelings concerning the Thai Sangha, as compared to the in-person interview. This differs from that of the factory workers, for whom $20.51 \%$ (8) answered "I'm neutral," $2.56 \%$ (1) answered "I agree," 5.13\% (2) answered "I agree very much," and $53.85 \%$ (21) of them answered "I don't know." The Thai factory workers will just follow the decision that is made because they neither care nor give much thought concerning the issues of the Thai Sangha, which is why the majority of them answered "I don't know" and "I'm neutral."

According to Dr. Montree, the Thai Sangha must follow the rules in the Tipitaka strictly because the Thai monks are Theravāda Buddhists. Therefore, the dual ordination method is the only ordination method that is currently acceptable in Theravāda Buddhism. Nevertheless, since the lineage of Theravāda bhikkhun̄ has already become extinct, thus, the Theravāda bhikkhun̄ ordination lineage is considered as non-revival (Peter Koret 2012: 130-131).

According to Dr. Kanjana, the Thai Sangha Act and the command of the $11^{\text {th }}$ Thai Supreme Patriarch violates the Thai constitution, which gives equal rights to males and females to partake in any religious activities that they have faith in as long as it does not violate the other citizens' rights. Furthermore, Dr. Kanjana adds that the order from the Thai Sangha Supreme Council forbidding the ordination of Theravāda bhikkhunīs in Thailand is also discrimination against Thai females according to the laws in the Thai constitution. Dr. Montree argues that even though the Thai constitution is considered as the highest law in Thailand, in reality, it has no power to govern over the Thai monks. Although the law in the Thai constitution gives rights to the Thai citizens to have faith in any doctrines they wanted, it lacks specific details about Buddhism as a distinct doctrine. In reality, Thai females should have the freedom to participate in any ritual and believe in any religious sect they wanted as long as it does not violate the human rights principle of equality in the Thai constitution. At the same time, those that shared the majority religious views (Thai bhikkhus) should neither discriminate against nor condemn minority religious views (Thai Theravāda bhikkhunīs). Nevertheless, the Thai monks must follow the law from the Thai Sangha Act, which is a system of governance designed to govern the Thai Sangha (Kanjana Suthikul 2017: 7).

According to Dr. Kanjana, the Thai Sangha Act is viewed as unfair because it does not accept Thai Theravāda bhikkhunīs as ordained monastics. According to her, the Thai Sangha Act not only violates the Thai constitution, it also goes against the Vinaya. Thus, females are not given the rights to ordain that they should have. According to Dr. Kanjana, the Buddha never said that females cannot ordain in his Vinaya. Thus, what the Thai Sangha Supreme Council did by forbidding the ordination of Thai females as a Theravāda bhikkhun̄ is considered "wrong." Moreover, it was a violation of the human rights principle when Thai Theravāda bhikkhunīs were refused entry into the Grand Palace to pay respect to the decreased King Rama IX in 2016. This is because the Thai Theravāda bhikkhunīs were not only entering the Grand Palace with their status as a "bhikkhunīs," but also as of Thai citizens.

Thus, what the Thai Sangha did is a violation of both the Thai constitution and Thailand's international obligations. It goes against the human rights principle according to its international treaties. Nevertheless, I am able to see improvements and amendments in the law, by which Thai Theravāda bhikkhunīs are now able to enter the Grand Palace to pay respect to the decreased King Rama IX. On the contrary, at this time, Thailand holds UN membership (and subscribes to many other conventions) only in name, since her deportment does not conform to the international obligations that the state promises. Thus, Thailand has been severely criticized by other nations. Therefore, Dr. Kanjana concludes that in the next 50 to 100 years, new Thai generations will be able to see that what these groups of Thai monks did (monopolization) was incorrect.

\subsection{CRS students and professors}

According to my interviews with two professors, Dr. Daeshowpon favors Theravāda bhikkhun̄ ordination in Thailand, whereas Dr. Watchara is opposed. According to Dr. Watchara, he thinks that the Thai bhikkhunīs who wanted to be accepted as "Theravāda" should re-name themselves as bhikkhunīs from the other Theravāda nikāyas or ordain from a Mahāyāna lineage. This is because the "old type" of ordination according to the Vinaya, such as dual ordination, can no longer be accomplished due to the disappearance of the Theravāda bhikkhunī lineage. Therefore, Dr. Watchara suggests a solution that we should ordain these bhikkhunīs and sāmaṇerīs, but accept them as a "new type," since the revival of Theravāda bhikkhunīs and sāmanerēs is no longer possible. Dr. Watchara believes that if the "new type" of bhikkhunī and sāmanerī ordination is permitted in Thailand, it will be beneficial for Thai Buddhism and society. However, Dr. Daeshowpon supports Theravāda bhikkhunī and sāmaṇerī ordination in Thailand. His opinion contradicts Dr. Watchara, in that he believes that there must be a method to revive the extinct Theravāda bhikkhunī ordination lineage so that Thai females 
can be ordained as a "Theravāda bhikkhun $\vec{\imath}$ " and be legally accepted as such. Thus, according to my opinion, Dr. Daeshowpon is suggesting that there is no need to rename these Thai Theravāda bhikkhunīs as a "new type," because the lineage could be re-instated if there is no interference with the rules in the Vinaya.

Nevertheless, conservative Thai professors and monks agreed with the Vinaya and the Tipitaka that dual ordination is the only correct ordination procedure in the present day. This is due to the fact that the Theravāda bhikkhunī ordination lineage was never introduced into Thailand (Hendrix, and Okeja: 2018: 144). However, Dr. Kanjana, a practising lawyer, prefers to think in terms of gender equality, equal human and feminist rights according to the Thai constitution in fighting for the validity of Thai Theravāda bhikkhunī ordination.

According to my questionnaires, when the CRS students are asked to list some of the topics discussed in their classroom about bhikkhunīs, the majority of the female CRS students tend to be more focused on the issue of bhikkhunīs' acceptances in Thailand than the male CRS students $(\mathrm{f}=10$, $\mathrm{m}=3$ ). In contrast, the majority of male CRS students tend to list the issue of the bhikkhunīs' non-acceptances in Thailand more often than the female students $(\mathrm{f}=5, \mathrm{~m}=7)$. From the questionnaires, $16.25 \%$ (13) of male and female CRS students answered "I agree very much," for there to be a bhikkhuni ordination in Thailand, 45\% (36) of them answered "I agree," and 35\% (28) of them answered, "I am neutral." $2.5 \%$ (2) of them answered "I disagree," for there to be bhikkhunī ordination in Thailand, and only 1 person $=1.25 \%$ answered "I disagree very much."

Of all the Thai male Buddhist professors I interviewed, all of them have been ordained as a bhikkhu before. Of all the Thai male CRS students from my sample, the majority of them have been ordained $=63.16 \%$ (24 persons). Of all the $63.16 \%$ of them that have been ordained, $50 \%$ (12 persons) of them are currently monks or sāmaneras. Out of the $63.16 \%$ of Thai male CRS students that have been ordained, $66.67 \%$ (16 persons) of them said that their reason for studying at CRS, Mahidol is because they are interested in the religious field. Thus, I find some correlation that Thai male professors who teach in the religious field and Thai male students who say that the primary reason they go to the College of Religious studies, Mahidol is because of their interest in religions tend to have some experiences ordaining in the monkhood.

\subsection{CRS students and factory workers}

According to my data analysis from the questionnaire sample, CRS students are more highly educated than the factory workers. Some of them also come from a higher social class. Therefore, their interest level and their support of Thai Theravāda bhikkhunīs ordination are also much higher than that of factory workers. From my data analysis, male students who said that their primary reason for studying at CRS, Mahidol is because they are interested in the religious field are $5.22 \%$ more interested in the issue of Theravāda bhikkhunīs than the average of all the male CRS students in the sample.

When the female CRS students were questioned, what would they ordained as if they were given a chance to ordain, $2.38 \%$ (1 person) said that she would like to ordain as a bhikkhunī, $2.38 \%$ (1 person) said that she would like to ordain as a sāmanererī, $11.9 \%$ (5 persons) said that they would like to become a mae-chi, whereas the majority $54.76 \%$ (23 persons) said that they would like to become a chi-phram. I also find that there is no significant difference between the interest level and opinions level in support of bhikkhunīs between CRS female and male students. This is similar to the case of female and male factory workers, in which there is not so much difference between them. Therefore, I conclude that gender does not play a major role in determining the differences in the interest level and opinions level in supportive of bhikkhunīs.

When I asked the CRS students and factory workers whether there should be bhikkhunī ordination in Thailand, CRS students of both genders showed overwhelming support, in which the majority $=45 \%$ (36) answered that they "agree," and $16.25 \%$ (13) answered that they "agree very much." Total $=61.25 \%$. However, when I put the same question to factory workers of both genders, the majority of them $=51.28 \%$ (20) answered "I don't know." The second highest choice among the factory workers is neutral $=28.21 \%$ (11). Thus, I find that CRS, Mahidol students are more probhikkhunī ordination than factory workers. However, there are also some students who believe that the lineage of Theravāda bhikkhuni ordination cannot be revived $=21.25 \%$ (17)--> "17.5\% (14) agree" + "3.75\% (3) agree very much," and that if females are accepted into the Sangha, sexual misconduct will occur $=46.25 \%$ (37) $->$ "37.5\% (30) agree" $+" 8.75 \%$ (7) agree very much." Furthermore, some of the CRS students believe that becoming a mae-chi or chi-phram is already sufficient enough for Thai females $=18.75 \%(15)$ -> " $17.5 \%$ (14) agree" + “ $1.25 \%$ (1) agree very much." From looking at the statistics, I conclude that the CRS students can show more of their support to make the future of Thai Theravāda bhikkhunīs promising. Nevertheless, I cannot say the opposite that Thai factory workers are against bhikkhunī ordination due to the Thai factory workers' lack of information and knowledge concerning bhikkhunīs. This is also because the Thai factory workers are not saying directly that they are against Thai Theravāda bhikkhun̄ ordination in Thailand, so therefore I cannot represent their view.

According to the questionnaire question, when the CRS students of both genders are asked whether ordination should be given to females as a Theravāda bhikkhunī and as a sāmanerer so that they have the same opportunity to study dhamma as deeply as bhikkhus, the majority of them answered "I agree"-> 42.5\% (34 students). The second highest choice among the CRS students of both genders answered "I agree very much"--> 23.75\% (19 students). Total $=66.25 \%$ (53). Thus, education plays an important factor in determining the interest level and opinions supportive of bhikkhunis of the CRS students compared to the factory workers (males and females combined) in which $51.28 \%$ (20) of them answered "I don't know." The second highest choice among them is $15.38 \%$ (6), in which they answered "I am neutral." 


\subsection{Villagers and factory workers}

Factory workers from Siam Pokaphan Company in Nakornpathom Province generally have no idea what a Theravāda bhikkhunī is, because the majority of them never heard of the term "bhikkhun $\overrightarrow{1}$ " before $64.1 \%$ (25), have never read news about bhikkhunīs 79.49\% (31), never met a bhikkhunī in person and never made merit with one $92.31 \%$ (36). This is because the number of Theravāda bhikkhunīs is only approximately 300 , which is considered as very minimal in Thailand. Furthermore, factory workers are not interested in religious issues, in which they only follow the mainstream traditional religious teachings. However, the villagers around Wat Songdhammakalyani are familiar with Bhikkhun̄̄ Dhammanandā (ธัมมนันทา) and her fellow bhikkhunī disciples. This is because the villagers often meet Bhikkhun̄̄ Dhammanandā's disciples, comprising bhikkhun̄̄s and sāmaṇerīs on their alms-round in the morning. On the factory workers' questionnaires completed in May 2017, when asked about whether offering to monks earns more merit than offering to bhikkhunīs, $61.54 \%$ (24) of them replied that they do not know. This sharply contrasts with the opinions of the villagers around Wat Songdhammakalyani (4) and also villagers at Pathum Thani (4), in which they believe that offering to both bhikkhunīs and monks brings the same amount of merit.

The majority of the Pathum Thani villagers in my interview sample respond that the state of the mind when giving the donation to the receiver determines the amount of merit one gets. Thus, they believe that there is no difference between giving to female or male ordained monastics. Nevertheless, there is one female villager from Pathum Thani province who says giving to bhikkhunīs brings more merit than giving to mae-chis because of their higher number of precepts. Another female villager from Pathum Thani province says she is more delighted when giving alms to the two bhikkhunīs (Dhammadatā and Dhammavijjā) because she is able to understand the Thai blessings (not Pali) that were given in return. Since the number of Theravāda bhikkhunīs in Thailand is very small (approximately 300), almost all of the factory workers never had a chance to meet and make merit with one. Therefore, they do not know what a bhikkhunī is.

Although the villagers around Wat Songdhammakalyani who give alms to bhikkhunīs come from a lower class like the factory workers, they are familiar with bhikkhunīs and know who Bhikkhun̄ Dhammanandā is. One interesting finding involved a male villager (Tawisak) from Pathum Thani province who likes to read history books and who is also the father of Bhikkhunī Dhammadatā. Tawisak has studied the history of Narin Phasit in depth. Narin Phasit was the first person in Thai history to initiate the bhikkhuni and sāmanerē ordination in Thailand (Peter Koret: 2012: 111). Therefore, he may be considered the first Thai feminist to fight for the Thai bhikkhuni ordination. Tawisak explains that it was the ordination of Narin Phasit's two daughters that made the $11^{\text {th }}$ Thai Supreme Patriarch issue command forbidding the ordination of Thai females as Theravāda sāmaṇerīs, sikkhamānās, or bhikkhunīs. He adds further that because it was the command of the $11^{\text {th }}$ Supreme Patriarch, no one dared to violate it.

\subsection{Factory workers, mae-chis and monks}

On the questionnaires, when asked whether ordination as a chi-phram and as a mae-chi is sufficient for Thai females, $33.33 \%$ (13) of factory workers replied "I agree" and $2.56 \%$ (1) replied "I agree very much." This is similar to four of the monks' opinions (Sunthorn, Wirat, Somboon, Tongdi) and two of the mae-chis' opinions (Kritsana, Nahathai). Since Phra Sunthorn Ñāṇsundaro, Phra Mahā Wirat Abhiratano, Phra Mahā Somboon Vuḍḍhikaro and Phra Mahā Tongdi Suratejo came from rural areas in Thailand, I hypothesize that they will tend to stick to the norm of mainstream Buddhist tradition in which females are usually ordain as only a mae-chi or a chi-phram. They are not accustomed to seeing females ordain as a bhikkhunī or a sāmaṇerī. This hypothesis is supported by a questionnaire question in which I asked the female factory workers what they would like to ordain as if given a chance. $26.92 \%$ (7) would like to become a mae-chi, and $34.62 \%$ (9) of them would like to become a chi-phram. Therefore, I hypothesize that the goal of ordaining as a bhikkhunī or as a sāmaṇerī seems too highended for the female factory workers; they think it could not be accomplished. Thus, I hypothesize further that most of the male factory workers ordained as a Theravāda monk simply because they were following the traditional Buddhist norms in Thai culture for a short duration, and they do not know much about Thai Theravāda bhikkhunīs or their own monkhood in-depth.

\subsection{Conclusion:}

According to the beliefs of Thai Theravāda bhikkhunīs and the sāmaṇerī in my interview sample, most of them believe that both males and females have the same ability to attain enlightenment. This is because enlightenment is not conditioned by gender. Moreover, the majority of them (Dhammavaṇn̄ā, Dhammavijjāa, Dhammakarun̄ā) believe that the Buddha foresaw that bhikkhunīs will help propagate his Buddhist dhamma teachings since one of the groups that belonged to his fourfold assembly consisted of bhikkhunīs. According to Phra Mahā Tongdi Suratejo, the state of a normal female lay person cannot absorb all the power of the merit after she has attained the status of an "arahant" because a lay person only has five precepts. Thus, her body will disintegrate. In order to prevent this from happening, she must be ordained as a bhikkhun̄ within 7 days after attaining enlightenment. However, according to Phra Mahā Tongdi Suratejo, this is easier to say than to do, because there is no Buddha in the present day to preach to anybody for them to gain enlightenment. According to Bhikkhun̄ Dhammavijjā and Bhikkhun̄̄ Dhammavaṇnā, mae-chis are more oppressed in Thai society when compared to bhikkhunīs and sāmaṇerīs because they must serve monks with their routine chores. Therefore, this is considered as unfair and is a form of gender discrimination.

Although the Buddha came up with the dual ordination method in the Vinaya, the old single ordination method was never abolished (Anālayo 2013: 327). Thus, I believe it is possible for the Theravāda bhikkhunī ordination lineage to be revived. Furthermore, the Buddha intended for there to be a fourfold assembly which included bhikkhunis to help spread his teachings (Dhammananda 2010: 157). The 
Buddha did come up with the command before his parinibbāna that the small rules in the Tipitaka could be amended later onwards (P.A. Payutto 2011: 255). For example, there is a rule that forbidden monastics from touching money, which is no longer possible for monks to follow in the present day. Thus, the rules in the Vinaya which some people interpreted as meaning that the dual ordination method is the only correct way should be amended, so that Theravāda bhikkhunī ordination could be revived.

Some of the mae-chis and bhikkhunīs I have interviewed mentioned a stigma in Thai society, that those who decided to ordain as a mae-chi are heartbroken females seeking a safe haven in Buddhism. However, not all of them agreed with this view and think highly of their own status as a female renunciate. However, the position of mae-chi is ambiguous in Thai society where there are perceived as only upāsikās and not as female ordained monastics (Duan Kamdee 2001: 232). Nevertheless, most of the reasons that Theravāda bhikkhunīs gave for their upasampadā ordination seem much more sophisticated to me. Significantly, contrary to the mainstream stereotypes, females candidates decided to become a bhikkhunī because they wanted to escape from the "endless cycle of death and rebirth." However, many females' motives for ordination originated not only from purely Buddhist motives, but also to break the Thai stereotype, traditional culture, and established norms of females as sexual objects (Charles F. Keyes 1984: 234 235). This may be due to the rise in education level over the years, in which females preferred to ordain as a Theravāda bhikkhunī instead of a mae-chi, in order to become more independent. Thus, I find that while mae-chis tend to be ambivalent toward Theravāda bhikkhunī ordinations, the majority of the monks are outright against Thai Theravāda bhikkhunīs.

Since the Thai monks are Theravāda Buddhists, they argued that they must follow the rules and teachings of the Tipitaka strictly (Peter Koret: 2012: 131). According to their argument, this is because Theravāda Buddhism is the strictest form of Buddhism. They followed the command of the $11^{\text {th }}$ Thai Supreme Patriarch, in the year 1928 CE. (พ.ศ. 2471) forbidding the ordinations of Thai females as a sāmaṇerī, sikkhamānā, or bhikkhunī. Nevetheless, one of the bhikkhunī (Dhammavijjā) argues that the reason this command has not been abolished yet is because the new Thai Supreme Patriarch does not dare to defy the command of the older one, like a student who is obedient to his ajarn. According to Bhikkhun̄i Dhammavannāa, the $11^{\text {th }}$ Thai Supreme Patriarch's command violates the current Thai constitution laws. In reality, his command in $1928 \mathrm{CE}$ should have already expired due to the laws in the Thai constitution that arose in the year $1932 \mathrm{CE}$ (พ.ศ. 2475). Currently, Thai bhikkhus cannot give upasampadā ordination to Thai females, and foreign monks cannot enter into Thailand to give upasampadā ordination to Thai females as well (Kanjana Suthikul 2017: 5-8).

\section{References}

[1] S.J. Tambiah. (1980). "Buddhism and the Spirit Cults in North-east Thailand." Great Britain: Cambridge University Press.

[2] Anālayo. (2013). "The Legality of Bhikkhunī Ordination." Journal of Buddhist Ethics 20, 310 - 333.

[3] Duan Kamdee. (2001). เดือน คำดี (2544). "The Bhikkhuni in Buddhism: An Analytical study." (Thai: รายงานวิจัย เรื่อง ภิกษุณีในพระพุทธศาสนา).

[4] Koret, Peter. (2012). The Man Who Accused the King of Killing a Fish: The Biography of Narin Phasit of Siam (1874-1950). Chiang Mai: Silkworm Books.

[5] Dhammanandā Bhikkhunī. (2010). "A Need to Take a Fresh Look at Popular Intepretations of the Tripitaka: Theravāda Context in Thailand" in Dignity and Discipline Reviving Full Ordination for Buddhist Nuns. Edited by Thea Mohr \& Jampa Tsedron. Somerville, MA: Wisdom Publications.

[6] Monica Lindberg Falk. (2000). "Thammacarini Witthaya: The First Buddhist School for Girls in Thailand" in Innovative Buddhist Women: Swimming Against the Stream. Edited by Karma Lekshe Tsomo. Richmond, Surrey: Curzon Press.

[7] Gyatso, Janet. (2010). "Female Ordination in Buddhism: Looking into a Crystal Ball, making a Future" in Dignity and Discipline Reviving Full Ordination for Buddhist Nuns. Edited by Thea Mohr \& Jampa Tsedron. Somerville, MA: Wisdom Publications.

[8] Donald K. Swearer. (1995). "The Buddhist World of Southeast Asia. New York, Albany: State University of New York Press.

[9] Muecke, Marjorie. (2004). "Female Sexuality in Thai Discourses about Maechii," Culture, Health, \& Sexuality 6, 221-238. 
[10] Kanjana Suthikul. (2017). (กาญจนา สุทธิกุล. 2560). Law that bhikkhun(nis) must know. (Thai: กฎหมายที่ภิกษุ(ณี)ต้องรู้).

[11] Scott E. Hendrix, Uchenna Okeja. (2018). "The World's Greatest Religious Leaders: How Religious Figures Helped Shape World History." Volume 1. Santa Barbara, California: ABC-CLIO.

[12] Phra Brahmagunabhorn (P.A. Payutto). (2011). พระพรหมคุณาภรณ์ (ป.อ. ปยุตุโต). (๒๕๕๕). "Answering Dr. Martin: Buddhist Vinaya for Bhikkhunis." (Thai: ตอบ ดร.มาร์ติน: พุทธวินัยถึงภิกษุณี). พิมพ์ครั้งที่สาม. นนทบุรี: บริษัท สหมิตร พริ้นติ้งแอนด์พับลิสชิ่ง จำกัด.

[13] Charles F. Keyes. (1984). "Mother or Mistress but Never a Monk: Buddhist Notions of Female Gender in Rural Thailand." American Ethnologist 11, 223241. 